\title{
Peningkatan Aktivitas dan Hasil Belajar Siswa dalam Turunan Fungsi Melalui Model Pembelajaran Jigsaw Berbantuan Student Activities Handout
}

\author{
Khoirul Anwar \\ Guru Matematika SMA 1 Dempet Demak \\ Email: khoirulanwarok@gmail.com
}

\begin{abstract}
Abstrak
Penelitian ini bertujuan untuk mengetahui aktivitas dan hasil belajar siswa pada materi turunan fungsi akibat pembelajaran yang menggunakan model pembelajaran Jigsaw berbantuan Student Activities Hand Out. Penelitian ini merupakan penelitian tindakan kelas dengan tiga siklus. Subyek penelitian ini siswa kelas XI IPA-2 SMA Negeri 1 Dempet Demak semester genap tahun pelajaran 2013/2014. Pengambilan data dalam penelitian ini menggunakan teknik observasi dan angket yang selanjutnya dianalisis sebagai data kualitatif, serta penilaian hasil ulangan blok dianalisis sebagai data kuantitatif. Hasil penelitian menunjukkan bahwa model pembelajaran Jigsaw berbantuan student Activities Hand Out dapat meningkatkan hasil belajar siswa dengan rata-rata mencapai 7,45 dengan jumlah siswa yang tuntas mencapai $86,67 \%$, aktivitas siswa mencapai $91,67 \%$ dengan tingkat kerja sama 3,75 (baik sekali) dan antusiasme 4,00 (baik sekali), dan respon siswa terhadap model pembelajaran yang telah diterapkan adalah sangat positif $(79,17 \%)$. Oleh karena itu, model pembelajaran Jigsaw berbantuan student Activities Hand Out dapat diterapkan pada pembelajaran matematika, khususnya turunan fungsi.
\end{abstract}

Kata Kunci: Jigsaw, Student Activities Hand Out

\begin{abstract}
The objective of this research was to determine the activity and student learning outcomes in the material derivative of the function due to the used of Jigsaw with Hand out of Student Activities. This research was a classroom action research with three cycles. The subjects of this study was class XI IPA-2 SMAN 1 Dempet Demak second semester of the school year 2013/2014. The data collection in this study was using observation and questionnaires were then analyzed as qualitative data. And then evaluating test results were analyzed as quantitative data. The results showed that the learning model can improve student learning outcomes with the average reach 7.45. The number of students who completed the competence reached $86.67 \%$, and the student activity was reached $91.67 \%$ with the level of cooperation reached 3,75 (excellent) and the enthusiasm of 4.00 (excellent), and the students' response to learning model that has been applied was very positive (79.17\%). Therefore, aided student learning model Jigsaw activities Hand Out can be applied to the study of mathematics, especially on derivative function.
\end{abstract}

Keywords: Jigsaw, Student activities Hand Out

\section{Informasi Tentang Artikel}

Diterima pada : 3 November 2014

Disetujui pada : 2 Desember 2014

Diterbitkan : Desember 2014 


\section{PENDAHULUAN}

Matematika sering dianggap sebagai mata pelajaran yang sulit dan membosankan. Hal ini sesuai pendapat Setiawan (2008) yang mengatakan bahwa pandangan umum terhadap matematika merupakan mata pelajaran yang sukar dan menjemukan. Pandangan ini berpengaruh pada psikologis siswa sebelum materi matematika diberikan sehingga penguasaan konsep tidak dapat maksimal. Demikian juga, turunan fungsi yang merupakan salah satu materi penting di dalam matematika dianggap sukar. Banyak siswa yang mengalami kesulitan dalam memahami konsep-konsep yang ada. Mereka berpendapat turunan fungsi memiliki banyak rumus dan dalam penerapannya memerlukan pemahaman tinggi yang melibatkan banyak konsep. Hal ini sesuai pendapat Sholikhah (2009) yang mengatakan bahwa proporsi kesalahan siswa dalam menyelesaikan soal matematika pokok bahasan fungsi dan turunannya yaitu kesalahan konsep 36,25\% dari 251 kejadian kesalahan-kesalahan prosedur $22,71 \%$ dari 251 kejadian kesalahan, dan kesalahan teknis $41,04 \%$ dari 251 kejadian kesalahan yang dilakukan oleh siswa.

Di samping itu, model pembelajaran matematika yang diterapkan oleh beberapa guru cenderung monoton. Diawali menerangkan materi, memberi contoh, memberi latihan soal dan diakhiri memberikan PR. Proses pembelajaran yang monoton tersebut menyebabkan motivasi dan minat siswa mengikuti pelajaran menurun. Hal ini disebabkan pembelajaran yang dilakukan tersebut, dominasi guru sangat kuat. Hal ini sesuai pendapat Abba (2000) yang mengatakan bahwa kebanyakan guru menggunakan model pembelajaran yang bersifat konvensional dan banyak didominasi guru, sehingga mengakibatkan keaktifan siswa rendah.

Hal di atas, berdampak pada hasil belajar yang tidak mencapai KKM. Hal ini sesuai dengan hasil ulangan siswa kelas XI IPA-2 SMA Negeri 1 Dempet semester genap tahun pelajaran 2013/2014 pada kegiatan sebelum penelitian, dengan rata-rata hasil belajar 4,82 dengan nilai tertinggi 8,50 , nilai terendah 2,50 dan ketuntasan $10 \%$.

Oleh karena itu, diperlukan solusi dengan menerapkan model pembelajaran yang dapat meningkatkan hasil belajar, yaitu model pembelajaran kooperatif. Hal ini sesuai hasil penelitian yang menunjukkan bahwa belajar kooperatif merupakan pendekatan pembelajaran yang efektif di sekolah menengah dan model ini dianjurkan untuk diterapkan dalam pembelajaran matematika (Winarno, 2002). Dalam penelitian ini menggunakan Jigsaw. Hal ini sesuai pendapat Sularyo (2003) yang mengatakan bahwa kelebihan model Jigsaw adalah adanya kelompok ahli yang memberikan pembelajaran kepada anggota dalam kelompoknya. Sedang untuk meningkatkan aktivitas siswa diperlukan lembar kerja yang berisi aktivitas yang dilakukan siswa dalam mengikuti proses pembelajaran (Student Activities Hand out).

Ruang lingkup penelitian ini dibatasi pada siswa kelas XI IPA-2 SMA Negeri 1 Dempet Demak semester genap tahun pelajaran 2013/2014, dengan pokok bahasan Turunan Fungsi.

Rumusan masalah dalam penelitian ini adalah sebagai berikut: (1) Apakah aktivitas siswa kelas XI IPA-2 SMA Negeri 1 Dempet Demak semester genap tahun pelajaran 2013/2014 dalam pembelajaran yang menggunakan model pembelajaran model Jigsaw dengan berbantuan student activities hand out dapat ditingkatkan? dan (2) Apakah hasil belajar siswa kelas XI IPA-2 SMA Negeri 1 Dempet Demak semester genap tahun pelajaran 2013/2014 pada materi turunan fungsi dapat ditingkatkan melalui penerapan model pembelajaran Jigsaw dengan berbantuan student activities hand out?, serta (3) Bagaimana respon siswa terhadap penerapan model pembelajaran Jigsaw dengan berbantuan student activities hand out pada pembelajaran turunan fungsi ?

Selaras dengan permasalahan di atas, penelitian ini bertujuan untuk: (1) Mengetahui peningkatan aktivitas siswa kelas XI IPA-2 SMA Negeri 1 Dempet Demak semester genap tahun pelajaran 
2013/2014 dalam pembelajaran yang menggunakan model pembelajaran model Jigsaw dengan berbantuan student activities hand out; (2) Mengetahui peningkatan hasil belajar siswa kelas XI IPA-2 SMA Negeri 1 Dempet Demak semester genap tahun pelajaran 2013/2014 pada materi turunan fungsi akibat penerapan model pembelajaran Jigsaw dengan berbantuan student activities hand out; dan (3) Mengetahui respon siswa terhadap penerapan model pembelajaran Jigsaw dengan berbantuan student activities hand out pada pembelajaran turunan fungsi.

Ada 3 manfaat utama penelititna ini, yaitu: (1) Bagi sekolah: penelitian ini memberikan masukan kepada pihak-pihak terkait tentang manfaat model pembelajaran Jigsaw; dan Meningkatkan layanan pendidikan kepada masyarakat; (2) Bagi guru: hasil penelitian ini memberikan masukan kepada guru bahwa model pembelajaran Jigsaw dapat diterapkan dalam proses pembelajaran, khususnya pembelajaran matematika, dan memberi motivasi kepada guru untuk meningkatkan profesionalisme guru dalam proses pembelajaran melalui kreatifitas dalam menerapkan model-model pembelajaran; (3) manfaat bagi siswa, yaitu penelitian ini meningkatkan kemampuan siswa untuk bersosialisasi dengan teman dan kemampuan dalam mengkonstruksi pengetahuan yang ada melalui model pembelajaran Jigsaw, dan meningkatkan hasil belajar siswa dalam bidang studi matematika.

\section{Belajar dan Mengajar Matematika}

Menurut Gagne (dalam Dahar, 1989) belajar didefinisikan sebagai suatu proses dimana suatu organisme berubah perilakunya sebagai akibat pengalaman. Menurut Gagne (dalam Hidayat, 2004) fase-fase kegiatan belajar terdiri atas empat fase yang terjadi secara berurutan, yaitu: (1) Fase aprehensi (apprehention phase). Pada fase ini siswa menyadari adanya stimulus yang berkaitan dengan kegiatan belajar yang akan ia lakukan; (2) Fase akuisisi (acquisiton phase). Pada fase ini siswa melakukan akuisisi (pemerolehan, penyerapan, atau interna- lisasi) terhadap berbagai fakta, ketrampilan, konsep atau prinsip yang menjadi sasaran dalam kegiatan belajar tersebut; (3) Fase penyimpanan (storage phase). Pada fase ini siswa menyimpan hasil belajar yang ia peroleh dalam ingatan jangka pendek (short term memory) atau ingatan jangka panjang (long term memory); dan (4) Fase pemanggilan (retrieval phase). Pada fase ini siswa berusaha memanggil kembali hasil-hasil kegiatan belajar yang telah ia peroleh dan disimpan dalam ingatan, baik yang menyangkut fakta, ketrampilan, konsep maupun prinsip.

\section{Aktivitas Siswa}

Proses pembelajaran yang terjadi, melibatkan aktivitas siswa dan guru. Proses pembelajaran akan bermakna, apabila siswa terlibat secara aktif dalam proses pembelajaran. Aktivitas yang ditunjukkan siswa akan menentukan kualitas pembelajaran. Menurut Nasution (2004) pengajaran modern mengutamakan aktivitas siswa. Dengan demikian, pembelajaran dapat memberikan hasil yang optimal, apabila siswa mempunyai aktivitas yang tinggi dalam mengikuti pembelajaran, sedangkan guru bertindak sebagai fasilitator. Jadi pembelajaran yang efektif didominasi oleh aktivitas siswa.

Aktivitas siswa dalam pembelajaran merupakan keaktifan siswa dalam mengkonstruksi pengetahuan baru dengan dilandasi pengetahuan awal yang telah dimilikinya. Menurut Resnick (dalam Megawangi, 2005) belajar dipahami melalui tiga hal, yaitu: 1) Belajar merupakan sebuah proses konstruksi pengetahuan, bukan merupakan perekaman atau absorpsi pengetahuan; 2) Ketika belajar, seseorang perlu menggunakan pengetahuan yang dimiliki sebelumnya untuk mengkonstruksi pengetahuan baru; dan 3) Belajar sangat dipengaruhi oleh situsai ketika proses belajar itu terjadi. Dengan demikian, agar siswa dapat belajar secara optimal, maka siswa perlu mengkonstruksi secara aktif terhadap pengetahuan baru yang ada, dengan didukung oleh pengetahuan yang dimiliki sebelumnya dan situasi tempat berlangsungnya proses pembelajaran. Agar sis- 
wa dapat mengkonstruksi pengetahuan secara aktif, dapat dilakukan dengan diskusi kelompok. Pada kegiatan diskusi siswa dapat melakukan keaktifan seperti mengumpulkan informasi-informasi yang diperlukan, mengkomunikasikan pendapat, menimbang/menerima gagasan orang lain, atau mengambil kesimpulan. Semakin banyak aktivitas yang dilakukan siswa terhadap suatu materi, akan mempertinggi penguasaan siswa terhadap materi itu.

Menurut Piaget (dalam Nasution, 2004) seorang anak berfikir sepanjang ia berbuat, tanpa perbuatan, anak tak berfikir. Dengan demikian, aktivitas yang dilakukan siswa dalam proses pembelajaran meliputi keaktifan secara jasmani maupun rohani. Namun kedua-duanya saling berhubungan. Menurut Sriyono (1992) keaktifan jasmani maupun rohani meliputi: (1) Keaktifan inderawi, meliputi pendengaran, penglihatan, peraba dan lain-lain; (2) Keaktifan akal, meliputi memecahkan masalah, menyusun pendapat, mengambil kesimpulan dan lain-lain; (3) Keaktifan ingatan, meliputi menerima bahan pengajaran dan menyimpannya dalam otak serta suatu saat siap dan mampu mengutarakan kembali; (4) Keaktifan emosi, meliputi menaruh minat, merasa senang, berani dan lain-lain; (5) Sedang aktivitas dan sikap siswa dalam penelitian ini, meliputi; (6) Kehadiran siswa; (7) Bertanya/ menanggapi pertanyaan (jumlah siswa);

(8) Kemampuan memanfaatkan waktu;

(9) Kerja sama kelompok; dan (10) Antusiasme.

Aktivitas guru digunakan untuk mengetahui kemampuan guru dalam mengelola pembelajaran. Dalam penelitian ini, aktivitas guru yang diamati, meliputi: (1) Kesesuaian dengan skenario pembelajaran; (2) Membimbing/ mengarahkan siswa untuk berpartisipasi aktif dalam pembelajaran; (3) Pemantapan materi setelah presentasi siswa;

(4) Kemampuan mengevaluasi; dan (5) Pemberian penghargaan.

\section{Model Pembelajaran Jigsaw}

Model Jigsaw telah dikembangkan dan diuji coba oleh Elliot Aronson dan teman-teman di Universitas Texas, kemudian diadopsi oleh Slavin dan teman-teman di John Hopkins University (Ibrahim dkk., 2005). Pemikiran dasar dari teknik ini adalah memberikan kesempatan kepada siswa untuk berbagi dengan teman-teman yang lain, mengajarkan serta diajar oleh sesama siswa. Hal ini merupakan bagian penting dari proses belajar. Menurut Ibrahim dkk. (2005) langkah-langkah model Jigsaw adalah.

Tahap kooperatif: (a) Siswa dibagi dalam beberapa kelompok belajar dengan anggota 5-6 siswa yang heterogen. (b) Guru memberikan materi pelajaran dalam bentuk teks, permasalahan, pertanyaan, atau lembar kerja. (c) Masing-masing siswa dalam kelompok yang sama mendapat materi yang berbeda-beda.

Tahap ahli, (a) Siswa dari tiap kelompok yang mendapatkan materi yang sama dengan anggota kelompok lain selanjutnya berkumpul guna membentuk kelompok gabungan (kelompok ahli). Di sini mereka berdiskusi untuk membahas materi yang sama. (b) Dalam kelompok ahli, setiap anggota mendapatkan bantuan penjelasan atau jawaban permasalahan dari sesama anggota. Masing-masing anggota harus ahli / paham terhadap materi yang dipelajarinya.

Tahap lima serangkai, (a) Pada tahap ini masing-masing siswa yang telah ahli kembali pada kelompok asal. (b) Masing-masing siswa mengajar$\mathrm{kan} / \mathrm{memberi}$ informasi materi yang telah dikuasainya kepada teman-teman sekelompok. (b) Pada akhir tahap ini masing-masing kelompok mendapatkan pemecahan masalah yang merupakan hasil kerja sama satu kelompok. (c) Dalam kegiatan ini guru memantau kerja kelompok-kelompok kecil untuk mengetahui bahwa kegiatan berlangsung dengan lancar. (d) Selanjutnya guru mengevaluasi hasil belajar siswa. Skor yang diperoleh digunakan untuk mencari nilai perkembangan siswa.

Langkah-langkah model pembelajaran Jigsaw dalam penelitian ini, adalah sebagai berikut: (1) Siswa dibagi dalam beberapa kelompok dengan ber- 
anggotakan 3-4 siswa yang heterogen. (2) Guru membagi materi yang telah disiapkan kepada kelompok dalam student activities hand out. Masing-masing siswa dalam kelompok yang sama mendapat materi/tugas yang berbeda-beda. Selanjutnya kelompok tersebut mempelajari secara mandiri materi/tugas yang menjadi tanggung jawabnya. Setiap siswa mempunyai kewajiban menguasai materi yang menjadi tanggung jawabnya (diskusi kelompok asal). (3) Siswa dari tiap kelompok yang mendapatkan materi yang sama berkumpul membentuk kelompok diskusi (kelompok ahli). Di sini mereka berdiskusi untuk membahas materi yang sama. Dalam kelompok ahli, setiap anggota mendapatkan bantuan penjelasan atau jawaban permasalahan dari sesama anggota. Masing-masing anggota harus ahli/paham terhadap materi yang dipelajarinya. Apabila ada kesulitan, dapat berkonsultasi dengan guru secara bersama-sama. (4) Siswa yang telah ahli kembali ke kelompok sesuai petunjuk guru (tahap penularan), untuk membimbing temannya dalam mempelajari materi/ uji kompetensi yang ada (tutor sebaya). (5) Secara acak guru menunjuk siswa untuk mempresentasikan hasil di depan kelas. Jika diperlukan, siswa tersebut dan dibantu anggota kelompok lainnya memperjelas hasil diskusi dengan menggunakan alat peraga. (6) Dengan tanya jawab, guru mengungkap kembali secara singkat untuk melihat tingkat pemahaman siswa. Guru memberikan penekanan terhadap materi-materi yang telah disampaikan kepada siswa. (7) Guru memberikan evaluasi terhadap materi yang telah diberikan. (8) Guru memberi penghargaan atas hasil belajar yang ditunjukkan siswa.

\section{Student Activities Hand Out}

Student activities hand out merupakan lembar kerja siswa (LKS) yang berisi langkah-langkah yang sistematis dan terarah untuk mengaktifkan siswa dalam membangun pengetahuan yang ada.

Student activities hand out disusun dengan berdasar pada SK dan KD yang akan dicapai. SK dan KD yang ada dirinci menjadi tujuan pembelajaran yang akan dicapai pada setiap pertemuan, sehingga para siswa mengetahui tujuan yang akan dicapai. Dengan demikian, siswa makin terarah dalam kegiatan pembelajaran yang ada.

Dalam student activities hand out, siswa dapat melengkapi materi yang ada, dengan mengisi titik-titik sesuai dengan algoritma yang ada. Hal ini diharapkan, para siswa dapat mengkonstruksi pengetahuan yang ada, sehingga penguasaan materi lebih tertanam dan tidak mudah lupa.

Uji kompetensi yang ada dalam Student activities hand out dijiwai oleh model pembelajaran yang diterapkan, yaitu Jigsaw. Pembagian tugas yang harus dikerjakan oleh siswa diatur dalam RPP, sehingga para siswa memperoleh tugas yang berbeda, meski dalam satu kelompok.

\section{Penelitian yang Relevan}

Pendapat Sularyo (2003) yang mengatakan bahwa kelebihan model Jigsaw adalah adanya kelompok ahli yang memberikan pembelajaran kepada anggota dalam kelompoknya.

\section{Kerangka Berfikir}

Kerangka berfikir dapat dilihat pada Gambar 1.

\section{Hipotesis Tindakan}

Berdasarkan permasalahan penelitian, disusunlah hipotesis tindakan penelitian ini, yaitu: (1) Melalui penerapan model pembelajaran Jigsaw dengan berbantuan student activities hand out diduga dapat meningkatkan aktivitas siswa kelas XI IPA-2 SMA 1 Dempet semester genap tahun pelajaran 2013/2014; (2) Melalui penerapan model pembelajaran Jigsaw dengan berbantuan student activities hand out diduga dapat meningkatkan hasil belajar siswa kelas XI IPA-2 SMA 1 Dempet semester genap tahun pelajaran 2013/2014; dan (3) Respon siswa terhadap pembelajaran yang menggunakan model pembelajaran Jigsaw dengan berbantuan student activities hand out diduga positif. 


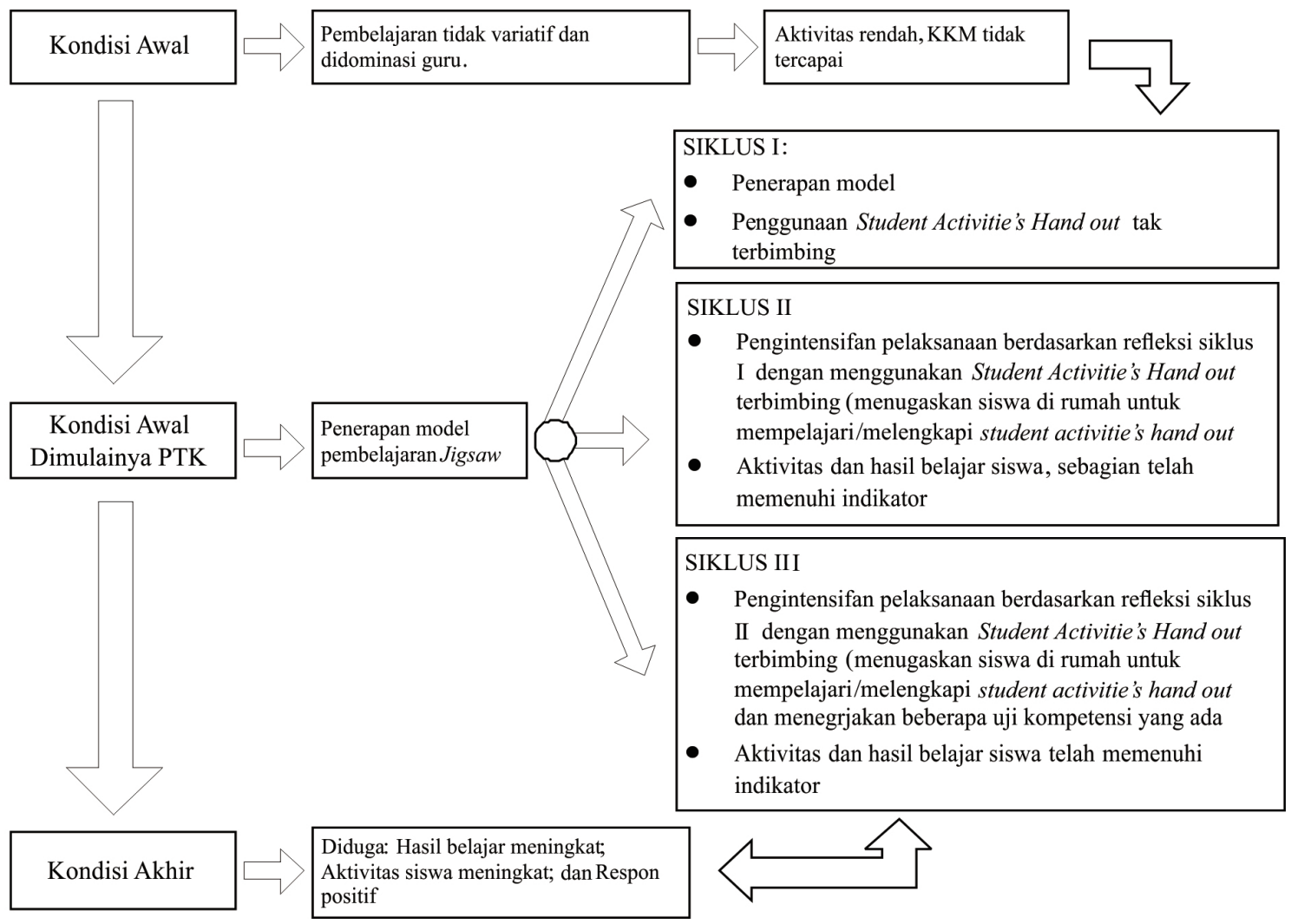

Gambar 1: Skema Kerangka Berfikir

\section{METODE}

\section{Setting Penelitian}

Subyek penelitian ini adalah siswa kelas XI IPA-2 SMA Negeri 1 Dempet Demak semester genap tahun pelajaran 2013/2014, yang berjumlah 30 siswa. SMA Negeri 1 Dempet Demak merupakan sekolah pinggiran dengan input yang rendah dan status sosial-ekonomi orang tua siswa menengah ke bawah. Penelitian ini berkolaborasi dengan dua orang guru matematika yang lain. Penelitian ini dilakukan pada bulan Februari-Mei 2014. Kelas XI IPA-2 merupakan kelas yang diampu oleh peneliti.

\section{Alat Pengumpul Data dan Analisis Data}

Alat pengumpul data yang digunakan adalah: (1) Teknik dokumentasi, digunakan untuk memperoleh data langsung dari tempat penelitian, yang meliputi nama subjek penelitian dan hasil ulangan blok; (2) Teknik Tes, digunakan untuk mengetahui hasil belajar siswa. Instrumen yang digunakan adalah soal tes hasil belajar; (3) Teknik Angket, di- gunakan untuk mengetahui tanggapan siswa tentang model pembelajaran yang digunakan. Instrumen yang digunakan berupa angket; dan (4) Teknik Observasi/pengamatan, digunakan untuk mengetahui aktivitas siswa dalam pembelajaran. Instrumen yang digunakan lembar pengamatan.

Ada dua variabel yang akan diungkap yaitu: 1) Variabel aktivitas siswa dan hasil belajar matematika siswa kelas XI IPA-2 SMA Negeri 1 Dempet Demak semester genap tahun pelajaran 2013 / 2014 pokok bahasan turunan fungsi, dan 2) Variabel model pembelajaran Jigsaw berbantuan student Activities Hand Out.

\section{Indikator Keberhasilan}

Sebagai penanda keberhasilan tindakan, disusunlah indikator keberhasilan sebagai berikut: (1) Aktivitas siswa dikatakan meningkat apabila aktivitas para siswa dalam mengikuti proses pembelajaran minimal $86 \%$, dan sikap siswa minimal 3,51 dengan tingkat kerja sama 3,51 dan antusiasme 3,51; (2) Hasil be- 
lajar dikatakan meningkat jika rata-rata hasil belajar minimal 7,30 dan jumlah siswa yang mencapai ketuntasan $(\geq$ 7,00) minimal 85\%. KKM SMA Negeri 1 Dempet tahun pelajaran 2013 / 2014 sebesar 7,0; dan (3) Respon siswa dikatakan baik apabila respon postif minimal mencapai $75 \%$ dari jumlah siswa yang ada.

\section{Prosedur Penelitian}

Penelitian ini menggunakan penelitian tindakan kelas. Dalam penelitian ini, peneliti (guru pengampu) dibantu oleh dua guru matematika sebagai kolaborator. Menurut Arikunto (2006) penelitian tindakan kelas diawali perencanaan tindakan (planning), penerapan tindakan (action), mengobservasi dan mengevalusai proses dan hasil tindakan (observation and evaluation), dan melakukan refleksi (reflecting), dan seterusnya sampai perbaikan yang diharapkan tercapai. Hasil refleksi suatu siklus digunakan untuk memperbaiki tindakan yang dilaksanakan pada siklus berikutnya.

Penelitian tindakan kelas ini dilaksanakan 3 siklus yaitu:

\section{Siklus I}

Tahap perencanaan tindakan. (a) Mengadakan pertemuan dengan guru matematika yang lain untuk membicarakan tentang problematika pembelajaran matematika, yaitu rendahnya aktivitas siswa mempelajari turunan fungsi, belum tercapainya KKM, pembelajaran yang monoton dan kurang aplikatif; (b) Mendiskusikan metode pembelajaran yang sesuai dengan problematika yang ada. Berdasarkan diskusi model pembelajaran yang dipilih adalah model pembelajaran pembelajaran Jigsaw berbantuan student Activities Hand Out; (c) Menyiapkan perangkat pembelajaran; (d) Menyiapkan pembentukan kelompok yang heterogen dengan berdasarkan nilai ulangan blok pokok bahasan sebelumnya (turunan fungsi aljabar) .

Tahap penerapan tindakan. Pelaksanaan proses pembelajaran meliputi pendahuluan, kegiatan inti dan penutup. Materi pada siklus I adalah turunan fungsi trigonometri.
Tahap observasi dan evaluasi. (a) Tahap observasi dilakukan pada saat pelaksanaan tindakan. Kolaborator mengamati aktivitas siswa dalam mengikuti proses pembelajaran. Di samping itu, kemampuan peneliti (guru) diamati dan dinilai oleh kolaborator. Pengamatan terhadap aktifitas siswa dan peneliti (guru) menggunakan lembar observasi yang telah disiapkan; (b) Tahap evaluasi dilaksanakan pada setiap akhir pertemuan berupa pop quiz dan setelah beberapa pertemuan berupa ulangan blok.

Tahap refleksi. (a) Pada akhir pertemuan dari siklus I diadakan evaluasi bersama yang dilakukan oleh guru (peneliti) dan kolaborator; (b) Dari hasil refleksi tersebut, jika ada kelebihan dipertahankan dan jika terdapat kekurangan akan diperbaiki pada siklus berikutnya.

\section{Siklus II}

Tahap perencanaan tindakan. Persiapan dilakukan berdasarkan hasil refleksi pada siklus I, kemudian dibuat perencanaan tindakan pada siklus II.

Tahap penerapan tindakan. Pelaksanaan tindakan ini merupakan pelaksanaan proses pembelajaran dengan perbaikan sesuai dengan hasil refleksi pada siklus I. Materi pada siklus II adalah fungsi naik dan fungsi turun, titik stasioner dan jenisnya serta menggambar grafik.

Tahap observasi dan evaluasi. Selama proses pembelajaran berlangsung, semua aktifitas siswa dan guru (peneliti) diamati oleh kolaborator dengan menggunakan lembar observasi yang telah disiapkan.

Pada siklus II juga diadakan evaluasi berupa pop quiz dan ulangan blok.

Tahap refleksi. Pada akhir pelaksanaan siklus II diadakan diskusi untuk mengetahui seberapa besar tindakan yang dilakukan telah memberikan hasil yang diharapkan.

\section{Siklus III}

Langkah-langkah pada siklus III sama dengan langkah-langkah pada siklus sebelumnya, dengan memperhatikan hasil refleksi siklus II. Materi pada siklus III adalah penerapan turunan fungsi. 


\section{HASIL DAN PEMBAHASAN Hasil Belajar Siswa}

Hasil belajar siswa pada ulangan blok dapat dilihat pada tabel 1. Berdasarkan tabel 1, dapat dikatakan bahwa ada peningkatan hasil belajar. Hasil ulangan blok pada pra siklus mempunyai rata-rata 4,82 dengan jumlah siswa yang tuntas mencapai $10,00 \%$. Hasil ulangan blok pada siklus I mempunyai rata-rata 4,62 dengan jumlah siswa yang tuntas mencapai $20,00 \%$. Pada siklus II meningkat menjadi 6,50 dengan jumlah siswa yang tuntas mencapai 56,67\%. Pada siklus III meningkat menjadi 7,45 dengan jumlah siswa yang tuntas mencapai $86,67 \%$.

Tabel 1. Hasil Belajar Siswa

\begin{tabular}{lcccc}
\hline \multicolumn{1}{c}{$\begin{array}{c}\text { Hasil } \\
\text { Belajar }\end{array}$} & $\begin{array}{c}\text { Pra } \\
\text { Siklus }\end{array}$ & $\mathbf{1}$ & $\begin{array}{c}\text { Siklus } \\
\text { 2 }\end{array}$ & $\mathbf{3}$ \\
\hline $\begin{array}{l}\text { Nilai Mini- } \\
\text { mum }\end{array}$ & 2,50 & 1 & 3 & 5 \\
Nilai Maksi- & 8,50 & 7,50 & 8,00 & 9,50 \\
mum & & & & \\
Rentang & 6,00 & 6,50 & 5,00 & 4,50 \\
Rata-rata & 4,82 & 4,62 & 6,50 & 7,45 \\
$\begin{array}{l}\text { Tingkat Ke- } \\
\text { tuntasan (\%) }\end{array}$ & 10,00 & 20,00 & 56,67 & 86,67 \\
\hline
\end{tabular}

\section{Hasil Pengamatan}

Hasil pengamatan aktivitas dan sikap siswa terhadap model pembelajaran yang diterapkan dapat dilihat pada tabel 2 .

Berdasarkan tabel 2, dapat dikatakan bahwa ada peningkatan aktivitas dan sikap siswa terhadap model pembelajaran yang diterapkan baik pada setiap pertemuan maupun pada setiap siklus. Pada pra siklus ratarata $67,50 \%$ siswa memenuhi aktivitas dan sikap yang diharapkan dengan tingkat kerja sama 1,50 (tidak baik) dan antusiasme 1,25 (tidak baik). Pada siklus I rata-rata 78,75\% siswa memenuhi aktivitas dan sikap yang diharapkan dengan tingkat kerja sama 2,00 (cukup baik) dan antusiasme 2,50 (cukup baik), kemudian meningkat pada siklus II menjadi $87,5 \%$ siswa memenuhi aktivitas dan sikap yang diharapkan dengan tingkat kerja sama 3,00 (baik) dan antusiasme 3,50 (baik), namun belum memuaskan (belum mencapai 85\% dan dengan tingkat kerja sama baik dan antusiasme baik sekali). Pada siklus III rata-ratanya menjadi
91,67\% siswa memenuhi aktivitas dan sikap yang diharapkan dengan tingkat kerja sama 3,75 (baik sekali) dan antusiasme 4,00 (baik sekali) dan telah memuaskan.

Hasil pengamatan terhadap kemampuan guru dalam pembelajaran dapat dilihat pada tabel 3. Berdasarkan tabel 3, dapat dikatakan bahwa ada peningkatan kemampuan guru dalam pembelajaran. Pada pra siklus rata-rata kemampuan guru dalam pembelajaran 2,55 . Pada siklus I rata-rata kemampuan guru dalam pembelajaran 3,10 , kemudian meningkat menjadi 3,45 pada siklus II, dan pada siklus III rata-rata kemampuan guru dalam pembelajaran mencapai 3,70 dan telah memenuhi indikator yang telah ditetapkan.

\section{Hasil Angket}

Hasil angket yang diberikan pada akhir pelaksanaan pembelajaran, dapat dilihat pada tabel 4. Berdasarkan tabel 4, dapat dikatakan respon siswa terhadap model sangat positif (baik) dengan rata-rata $79,17 \%$.

\section{Pembahasan}

Berdasarkan tabel 3, hasil belajar baik dapat dikatakan terjadi peningkatan. Hal ini disebabkan, siswa semakin terbiasa dan termotivasi untuk menguasai konsep. Hal ini sesuai angket bahwa siswa merasa model pembelajaran membantu pemahaman konsep turunan fungsi (80,00\%). Di samping itu, Student Activities Hand out yang ada, turut membantu siswa dalam memahami konsep-konsep yang ada, karena siswa dalam mengkonstruksi pengetahuannya lebih terarah. Hal ini sesuai pendapat Wijayanti (2008) yang mengatakan bahwa LKS memiliki beberapa kelebihan yaitu siswa lebih aktif dalam proses belajar mengajar karena siswa dapat mengembangkan, melatih keterampilan, dan memproses sendiri hasil belajarnya.

Refleksi yang dilakukan tiap siklus berkontribusi dalam peningkatan hasil belajar siswa. Hal ini disebabkan, refleksi yang dilakukan peneliti dan pengamat, berdasarkan hasil pengamatan yang dilakukan pada siklus yang bersangkutan dan hasil belajar siswa, sehingga pelak- 
sanaan siklus II memperhatikan hasil refleksi siklus I, begitu juga pelaksanaan siklus III memperhatikan hasil refleksi siklus II.

Berdasarkan tabel 2, hasil pengamatan terhadap sikap siswa dapat dikatakan mengalami peningkatan. Hal ini disebabkan, para siswa termotivasi untuk belajar yang lebih baik, sehingga siswa yang mengalami kesulitan secepatnya berusaha mengatasinya dengan bertanya kepada teman satu kelompok. Di samping itu, ada kesadaran dalam kelompok bahwa keberhasilan kelompok ditentukan juga keberhasilan anggotanya. Oleh karena itu, diperlukan kerja sama antar anggota kelompok dalam mengkaji materi dan mengerjakan uji kompetensi yang ada, artinya apabila ada siswa dalam kelompoknya mengalami kesulitan, maka siswa tersebut harus bertanya kepada anggota kelompok lain yang menguasai permasalahan itu dan yang bersangkutan harus membimbingnya sehingga kesulitan yang ada dapat teratasi. Dengan demikian, terjadi tutor teman sejawat yang memudahkan siswa memahami materi yang ada. Hal ini sesuai dengan pendapat Lie (2004) pengajaran oleh rekan sebaya ternyata lebih efektif dari pada pengajaran oleh guru. Setiap kelompok berusaha tampil maksimal dalam pembelajaran.

Di samping itu, aktivitas siswa juga dipengaruhi oleh kemampuan guru dalam memotivasi siswa, agar terlibat secara aktif dalam proses pembelajaran. Berdasarkan tabel 3, diperoleh ke- mampuan guru dalam membimbing/ mengarahkan siswa untuk berpartisipasi aktif dalam pembelajaran mengalami peningkatan dari 2,50 menjadi 3,75 (sangat baik). Dengan demikian, peningkatan kemampuan guru dalam memotivasi siswa, turut meningkatkan aktivitas siswa dalam pembelajaran.

Berdasarkan tabel 4, respon siswa terhadap model pembelajaran yang diterapkan sangat baik. Hal ini disebabkan siswa merasakan manfaat dari model pembelajaran model pembelajaran Jigsaw dan penggunaan student activities hand out. Manfaat yang dirasakan siswa diantaranya dapat melatih berkomunikasi dan bersosialisasi dengan teman yang lebih baik (80\%), dapat memotivasi untuk belajar lebih baik (80\%), dan student activities hand out yang ada membantu pemahaman konsep turunan fungsi $(76,67 \%)$.

\section{PENUTUP \\ Kesimpulan}

Berdasarkan penjelasan di atas, maka dapat disimpulkan sebagai berikut: (1) Model pembelajaran Jigsaw dapat meningkatkan aktivitas sebesar $91,67 \%$ dan sikap siswa sebesar 3,83 (baik sekali) dengan tingkat kerja sama 3,75 (baik sekali) dan antusiasme 4,00 (baik sekali); (2) Model pembelajaran Jigsaw dapat meningkatkan hasil belajar dengan rata-rata 7,45 dengan jumlah siswa yang tuntas mencapai $86,67 \%$; dan (3) Respon siswa terhadap model pembelajaran Jigsaw sangat positif yaitu $79,17 \%$.

Tabel 2. Hasil Pengamatan Aktivitas dan Sikap Siswa

\begin{tabular}{|c|c|c|c|c|c|c|c|c|}
\hline \multirow{2}{*}{ Aspek } & \multirow{2}{*}{ Rata-rata } & \multirow{2}{*}{$\begin{array}{c}\text { Pra } \\
\text { Siklus }\end{array}$} & \multicolumn{6}{|c|}{ Siklus } \\
\hline & & & 1 & Rata-rata & 2 & Rata-rata & 3 & Rata-rata \\
\hline $\mathrm{A}$ & 98,33 & \multirow{2}{*}{67,5} & 100 & \multirow{2}{*}{78,75} & 100 & \multirow{2}{*}{87,5} & 100 & \multirow{2}{*}{91,67} \\
\hline $\mathrm{B}$ & 36,67 & & 57,5 & & 75 & & 83,33 & \\
\hline $\mathrm{C}$ & 1,25 & \multirow{3}{*}{1,33} & 2,25 & \multirow{3}{*}{2,25} & 2,75 & \multirow{3}{*}{3,08} & 3,75 & \multirow{3}{*}{3,83} \\
\hline $\mathrm{D}$ & 1,50 & & 2 & & 3 & & 3,75 & \\
\hline $\bar{E}$ & 1,25 & & 2,5 & & 3,5 & & 4,00 & \\
\hline
\end{tabular}

Keterangan:

A : Kehadiran (jumlah Siswa)

B : Bertanya/ Menanggapi pertanyaan (jumlah siswa)

C : Kemampuan memanfaatkan waktu

D : Kerjasama kelompok

E : Antusiasme 
Tabel 4. Hasil Angket

\begin{tabular}{lc}
\hline \multicolumn{1}{c}{ Aspek } & Persentase \\
\hline Siswa senang dengan model pembelajaran yang ada & 76,67 \\
Siswa merasa baru terhadap model pembelajaran yang ada & 90,00 \\
Siswa merasa model pembelajaran membantu dalam memahami konsep yang ada & 80,00 \\
Siswa dapat menyesuaikan dengan model pembelajaran yang ada & 73,33 \\
Siswa merasa model pembelajaran dapat melatih berkomunikasi dan bersosialisasi dengan & 80,00 \\
teman & 80,00 \\
Siswa merasa model pemebalajran dapat memotivasi untuk belajar lebih baik & 76,67 \\
Siswa berminat untuk mengikuti lagi pembelajaran seperti model pembelajaran yang dija- & 76,67 \\
lani saat ini & 79,17 \\
Hand out ang ada membantu pemahaman konsep & \\
Rata-rata &
\end{tabular}

\section{Saran}

Berdasarkan hasil penelitian dan pembahasan, maka disarankan hal-hal sebagai berikut: (1) Hendaknya guru menerapkan model pembelajaran Jigsaw dalam pembelajaran turunan fungsi; dan (2) Para peneliti dapat mengembangkan hasil penelitian ini lebih mendetail baik pada mata pelajaran matematika atau lainnya.

\section{DAFTAR PUSTAKA}

Abba, N. 2000. Pengembangan Perangkat Pembelajaran Matematika Berorientasi Model Pembelajarn Berdasarkan Masalah (Problem Based Instruction). Surabaya: PPs Universitas Negeri Surabaya.

Arikunto, S. 2006. Dasar-dasar Evaluasi Pendidikan. Jakarta: Bumi Aksara.

Dahar, R.W. 1989. Teori-teori Belajar. Bandung: Erlangga.

Hartoyo. 2006. Media Dan Alat Peraga. Bahan diskusi dalam semiloka di LPMP Jawa Tengah.

Hidayat, M.A. 2004. Teori Pembelajaran Matematika. Semarang: PPs UNNES.

Ibrahim, M.R; Fida N; Ismono, M. 2005. Pembelajaran Kooperatif. Surabaya: Universitas Negeri Surabaya.

Lie, A. 2004. Cooperative Learning, Mempraktekkan Cooperative Learning di Ruang-ruang Kelas. Jakarta: Gramedia.
Megawangi, R. 2005. Pendidikan Holistik. Jakarta: Indonesia Heritage Foundation.

Wijayanti, L.D. 2008. Pengembangan Lembar Kerja Siswa dengan Pendekatan Problem Solving pada Pokok Bahasan Persamaan Garis Lurus VII SMP. Skripsi tidak diterbitkan. Malang: Universitas Negeri Malang.

Nasution, S. 2004. Dikdaktik Asas-asas Mengajar. Jakarta. Bumi Aksara.

Setiawan. 2008. Strategi Pembelajaran Matematika. Yogyakarta: P4TK Matematika.

Solikah, F.D. 2009. Kesalahan Siswa Dalam Menyelesaikan Soal Matematika Pokok Bahasan Fungsi dan Turunannya Kelas XI IPA 1 Semester II SMA Muhammadiyah I Nganjuk. http://digilib.unitomo.ac.id (diakses pada tanggal 17 April 2014).

Sriyono. 1992. Teknik Belajar Mengajar Dalam CBSA. Jakarta: Rineka Cipta.

Sularyo. 2003. Upaya Meningkatkan Ketuntasan Belajar Fisika dengan Metode Belajar Kelompok dan Berwawasan Sets pada Siswa Kelas II SMUN 2 Semarang Tahun 2002-2003. Tesis.Semarang: PPs UNNES.

Winarno, 2002. Merancang Model Pembelajaran Matematika Berorientasi Pada Pakem dan Pembekalan Kecakapan Hidup. Yogyakarta: P3G Matematika. 